\title{
倍角差および観測差の統計学的考察 \\ STATISTICAL CONSIDERATION ON THE METHOD CHECKING AN ACCURACY OF THE OBSERVED DATA BY THE DIRECTION METHOD
}

\author{
近 津 博 文* \\ By Hirofumi CHIKATSU
}

\section{1. まえがき}

方向観測法は測点の周囲に多くの角が存在する場合, 各挟角を均一な精度で測定できることおよび測定の途中 あるいは終了直後において測定值の良否判定が容易に行 えるなどの理由によりわが国では一等三角測量以外の基 準点測量に広く利用されている方法であり，採用する対 回数, 選定すべき視準点数 および得られる測定值の精 度など方向観測法を行う際の詳しい説明が，たとえば Handbuch der Vermessungskunde など1),2) に述べられ ている.

方向観測法により得られる測定值の良否判定方法には いくつかの考え方がある ${ }^{3), 4)}$ そその一つは，まず望遠鏡 正位で零方向を視準し右回りに順次測定を進めていき， 最後の視準点に対する測定が終了したならば望遠鏡を反 位にして, 今度は左回りに測定を進め再び零方向の視淮 を行い，零方向に対する初読值と終読值との秒単位を比 較することにより 1 対回観測におりる器械の操作ミスな どを検討する，次に目盛盤の位置を換え，上記と同様な 操作を繰り返し何対回かの測定が終了したならば，各挟 角の值および各挟角の平均值を算出し，これらの各平均 值と各測定值との間にある制限値を定めておき, これ を測定值の 良否判定の 指標とする方法であり，これは National Geodetic Survey が推薦する方法の一つであ $3^{4)}$.

観測方法は上記と同じであるが，わが国では同一視隻 点に対する対回中の倍角の最大値と最小值との差を倍角 差，同様に較差のそれを観測差と称し測量の目的に応じ てそれぞれにある制限值を定め，この各制限值を指標と して測定值の良否判定を行うのが一般的である。しか し, 倍角差および観測差の各制限值についての理論的文 献は少なく，わずかに斉藤(5) および千葉ら ${ }^{6}$ がこの問題

* 正会員 工修 東京電機大学助手 理工学部建設工学科
を取り上げている程度である。

ある母集団から抽出した 1 組の無作為標本に対する順 序統計量の最大値と最小值との差は範囲であることを考 慮すると，倍角差および観測差は同一視淮点に対する各 対回ごとの倍角および較差の各值をそれぞれ 1 組の無作 為標本とする範囲となる.

本論文では範囲の理論を応用して倍角差および観測差 の各制限値を統計学的に考究した結果, 各制限值は倍角 および較差の各標準偏差, 採用する対回数および超過確 率とにより定められることを示し,さらにこれらが取り 得る種々の值と制限值との関連性を求める. また測定值 より求まる倍角差および観測差の各平均值と範囲の期待 值との比較を行うことによっても測定值の良否判定を行 うことが可能であることを示す.

一方，倍角差および観測差の誤差論的特徴を考虑する と, これらの各制限值では測定值に含まれる定量的な誤 差を評価することは不可能であるといら考えに基づき， 特に求心誤差の評価方法についても論及し, 最後に現在 一般的に使用されている各種測量器械の性能と倍角差, 観測差および閉合差などの各制限值との関連性について 検討を行う.

\section{2. 倍角差および観測差の統計学的考察}

\section{（1）倍角および較差の平均二乗誤差}

望遠鏡正および反での測定値に対する不定誤差をそれ ぞれ $\sigma_{r}$ および $\sigma_{l}$ とすると, 1 対回の正と反との測定 值の和㧍よび差，すなわち倍角および較差に対する不定 誤差は次式となる.

$$
\sigma_{(r \pm l)}= \pm 2 \sqrt{\alpha^{2}+\beta^{2}+\gamma^{2}}
$$

ここに, $\alpha$ : 視淮誤差, $\beta$ : 読み取り誤差, $r:$ 目盛分割 誤差

しかし，厳密には目盛分割誤差に対する考え方，すな 
わち $\gamma$ を $\alpha$ および $\beta$ と同様な不定誤差とするか, ある いは目盛盤の使用区間に対する定誤差と考えるか，さら に後者の場合，望遠鏡正 および反での目盛盤使用区間 が $180^{\circ}$ 異なっていることをどのように扱うかによって $\sigma_{(r \pm l)}$ の各式は異なる式となるが, 本研究では前者の考 え方を採用する.

\section{（2）範囲 $\boldsymbol{R}$ の密度関数および分布関数}

確率密度関数 $f(x)$ をもつ母集団から抽出した 1 組 の無作為標本としての 順序統訃量を $x_{(1)}, x_{(2)}, \cdots, x_{(\boldsymbol{n})}$ とすると, 最大值 $x_{(n)}$ と最小值 $x_{(1)}$ との差すなわち 範囲 $R\left(R=x_{(n)}-x_{(1)}\right)$ の密度関数 および分布関数は $x_{(1)}$ と $x_{(n)}$ との同時分布を考えることにより誘導され る. $v<u$ として $x_{(1)}$ が区間 $(v, v+d v)$ に落ちると 同時に $x_{(n)}$ が区間 $(u, u+d u)$ に落ちる確率を求める と, 多項分布を用いて

$$
\begin{array}{r}
h(u, v) d u d v=n(n-1) f(u) f(v) \\
\cdot\left\{\int_{v}^{u} f(x) d x\right\}^{n-2} d u d v \quad \ldots .
\end{array}
$$

ゆえに, 大きさ $n$ の標本の最大值 $u$ および最小值 $v$ の 同時密度関数は

$$
h(u, v)=n(n-1) f(u) f(v)\left\{\int_{v}^{u} f(x) d x\right\}^{n-2}
$$

一方範囲 $R=u-v$ の分布関数 $\Phi(R)$ および密度関数 $\phi(R) は^{7)} u$ および $v$ の取り得る範囲が $-\infty<v<u<$ のであることより，

$$
\begin{aligned}
\Phi(R) & =n \int_{-\infty}^{\infty} f(v)\left\{\int_{v}^{v+R} f(x) d x\right\}^{n-1} d v \\
& {[0 \leqq R<\infty] \ldots \ldots \ldots \ldots \ldots \ldots \ldots } \\
\phi(R) & =n(n-1) \int_{-\infty}^{\infty} f(v) f(v+R) \\
& \cdot\left\{\int_{v}^{v+R} f(x) d x\right\}^{n-2} d v \ldots \ldots(5)
\end{aligned}
$$

測定角は正規分布に従うと考えられるから 倍角 (較差) を確率変数 $x$ とする母集団も正規分 布に従い, その密度関数 $f(x)$ は

$$
f(x) \frac{1}{\sqrt{2 \pi} \sigma} \exp \left(-\frac{(x-\mu)^{2}}{2 \sigma^{2}}\right)
$$

ここに, $\sigma:$ 標準偏差, $\mu:$ 平均值

であるから，これを規準化すると式 (4) および 式（5）はそれぞれ次式となる.

$$
\begin{aligned}
& \Phi\left(R^{*}\right)=n \int_{-\infty}^{\infty} g\left(v^{*}\right)\left\{\frac{1}{\sqrt{2 \pi}} \int_{v^{*}}^{v^{*}+R^{*}}\right. \\
& \left.\cdot \exp \left(-\frac{t^{2}}{2}\right) d t\right\}^{n-1} d v^{*} \\
& \phi\left(R^{*}\right)=n(n-1) \int_{-\infty}^{\infty} g\left(v^{*}\right) g\left(v^{*}+R^{*}\right)
\end{aligned}
$$

$$
\cdot\left\{\frac{1}{\sqrt{2 \pi}} \int_{v^{*}}^{v^{*}+R^{*}} \exp \left(-\frac{t^{2}}{2}\right) d t\right\}^{n-2} d v^{*}
$$$$
\text { ここに, } g(t)=\frac{1}{\sqrt{2 \pi}} \exp \left(-\frac{t^{2}}{2}\right), v^{*}=\frac{v-\mu}{\sigma},
$$$$
R^{*}=\frac{R}{\sigma}
$$

しかし,これらの式は任意の $n$ に対して直接求積でき ないため数值積分法を用いる. $n=2 \sim 10$ の各 $n$ 值に対 する $R^{*}$ の分布関数および密度関数を数值積分により求 めた結果が図一1である.

また，おもな $n$ 值に対して $R^{*}$ がある特定の值 $R_{0}{ }^{*}$ 以下となる確率を表わしたものが 表一1 である.

一方， $R^{*}$ の期待值 $E\left(R^{*}\right)$ は

$$
\begin{array}{r}
E\left(R^{*}\right)=n(n-1) \int_{0}^{\infty} R^{*}\left[\int_{-\infty}^{\infty} g\left(v^{*}\right) g\left(v^{*}+R^{*}\right)\right. \\
\left.\cdot\left\{\frac{1}{\sqrt{2 \pi}} \int_{v^{*}}^{v^{*}+R^{*}} \exp \left(-\frac{t^{2}}{2}\right) d t\right\}^{n-2} d v^{*}\right] d R^{*}
\end{array}
$$

であり, $n=2 \sim 10$ の各 $n$ 值について数值積分を行った

$$
\text { 表一1 } R^{*} \leq \boldsymbol{R}_{0}^{*} \text { となる確率 }
$$

\begin{tabular}{c|c|c|c|c|c}
\hline \multirow{2}{*}{$R_{0}{ }^{*}$} & \multicolumn{5}{|c}{$P\left(R^{*} \leq R_{0}{ }^{*}\right)$} \\
\cline { 2 - 6 } & $n=2$ & $n=3$ & $n=4$ & $n=5$ & $n=6$ \\
\hline 0.5 & 0.270 & 0.063 & 0.014 & 0.003 & 0.001 \\
1.0 & 0.509 & 0.230 & 0.099 & 0.041 & 0.017 \\
1.5 & 0.699 & 0.445 & 0.271 & 0.160 & 0.093 \\
2.0 & 0.832 & 0.648 & 0.487 & 0.359 & 0.260 \\
2.5 & 0.915 & 0.804 & 0.689 & 0.581 & 0.484 \\
3.0 & 0.961 & 0.904 & 0.836 & 0.766 & 0.696 \\
3.5 & 0.984 & 0.958 & 0.925 & 0.888 & 0.848 \\
4.0 & 0.994 & 0.984 & 0.970 & 0.954 & 0.936 \\
4.5 & 0.998 & 0.995 & 0.990 & 0.984 & 0.976 \\
5.0 & 0.999 & 0.998 & 0.997 & 0.995 & 0.993 \\
5.5 & 1.000 & 1.000 & 0.999 & 0.999 & 0.998 \\
6.0 & 1.000 & 1.000 & 1.000 & 1.000 & 0.999 \\
\hline
\end{tabular}

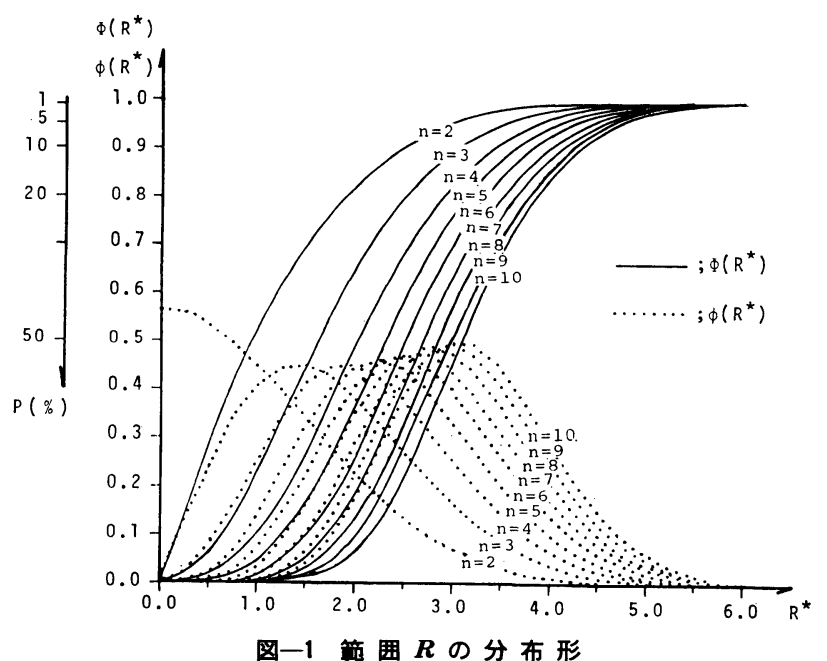


表一2 標 本 数 と $E\left(R^{*}\right)$

\begin{tabular}{c|c|c|c|c|c|c|c|c|c}
\hline $\begin{array}{c}\text { 標本数 } \\
n\end{array}$ & 2 & 3 & 4 & 5 & 6 & 7 & 8 & 9 & 10 \\
\hline$E\left(R^{*}\right)$ & 1.128 & 1.693 & 2.059 & 2.326 & 2.534 & 2.704 & 2.847 & 2.970 & 3.077 \\
\hline
\end{tabular}

結果が 表一2 である.

\section{（3） 倍角差（観測差）の制限値}

方向観測法を行う際の対回数は前節で述べた標本数に 対応する. いま, 図一1 中の対象とする対回数 $n$ の累積 分布曲線において, ある超過確率 $P \%$ に対する $R^{*}$ の 值を読み取れば，この值が $n$ 対回観測時の超過確率 $P \%$ に対応する規準化された倍角差（観測差）の制限值とな る.これを便宜上 $R_{P}{ }^{*}$ と書く.

そこで超過確率 $P$ を $1 \%$ とするとき，標準偏差 $\sigma$ を もつ標本より求められた $R^{*}$ の值が，与えられた $n$ に対 して 図一1 上り求まる $R_{1}{ }^{*}$ の值を現実に越えるとする ならば，そのような現象の実現する確率がわずか $1 \%$ で あるにもかかわらず，それが現実に生じたということか ら， $R^{*}$ の構成要素である最大值および最小值の少なく とも一方は与えられた $\sigma$ をもつ母集団からの測定值で はないとして $R_{1}{ }^{*}$ を越える対回数について再測を行わ なければならないとする（この場合，母集団に属する測 定值であるにもかかわらず測定の誤りとする危険率が 1\% だけ存在する)

しかし, 超過確率 $P$ の值は使用する器械の性能およ び測量の目的に応じて種々に変化すべき性質のものであ り,さらに $R_{P}{ }^{*}$ の值は対回数 $n$ に影響される. そこ で, 本研究では対回数 $n$ が $2 \sim 6$ の各場合について, そ れぞれ 5 通りの超過確率 $(1,5,10,20$ および $50 \%)$ に 対応する $R_{P} *$ の值を求め, その結果を示したものが 表 一3である。

ところで，表一3 より得られる制限值 $R_{P} *$ は

$$
R_{P}^{*}=\frac{R_{P}}{\sigma}
$$

であるから，実際に方向観測を行う際の指標となる制限 值 $R_{P}$ は

$$
R_{P}=\sigma \cdot R_{P} *
$$

倍角および較差を確率変数とするそれぞれの母集団の 標準偏差 $\sigma_{(r+l)}$ 拈よび $\sigma_{(r-l)}$ は式 (1) より算出され, また $R_{P}{ }^{*}$ の值は対回数 $n$ および超過確率 $P$ に対応し て 表一3 より定められる. 結局, $n$ 対回観測時の超過確

$$
\text { 表一3 } n \text { および } \boldsymbol{P} \text { と } \boldsymbol{R}_{P}{ }^{*} \text { の值 }
$$

\begin{tabular}{r|c|c|c|c|c}
\hline$P(\%)$ & $n$ & 3 & 4 & 5 & 6 \\
\hline 1 & 3.80 & 4.27 & 4.53 & 4.77 & 4.93 \\
5 & 2.88 & 3.43 & 3.78 & 3.97 & 4.18 \\
10 & 2.41 & 2.98 & 3.36 & 3.59 & 3.80 \\
20 & 1.88 & 2.49 & 2.88 & 3.14 & 3.34 \\
50 & 0.98 & 1.64 & 2.03 & 2.32 & 2.54 \\
\hline
\end{tabular}

率 $P \%$ に対する倍角差の制限值 $\hat{R}_{P}$ および観測差の制 限值 $\dot{R}_{P}$ は

$$
\begin{aligned}
& \hat{R}_{P}=\sigma_{(r+l)} \cdot R_{P} * \\
& \dot{R}_{P}=\sigma_{(r-l)} \cdot R_{P} *
\end{aligned}
$$

\begin{tabular}{|c|c|c|c|c|c|c|c|}
\hline$\sigma_{(r+l)}(")$ & $n$ & $P(\%)$ & $\hat{R}_{P}\left(\dot{R}_{P}\right)\left({ }^{\prime \prime}\right)$ & $\| \sigma_{(r+l)}(")$ & $n$ & $P(\%)$ & $\hat{R}_{P}\left(\dot{R}_{P}\right)(")$ \\
\hline \multirow{25}{*}{ \pm 5} & \multirow{10}{*}{3} & 1 & 19 & \multirow{25}{*}{ \pm 15} & \multirow{5}{*}{2} & 1 & 57 \\
\hline & & 5 & 14 & & & 5 & 43 \\
\hline & & 10 & 12 & & & 10 & 36 \\
\hline & & 20 & 9 & & & 20 & 28 \\
\hline & & 50 & 5 & & & 50 & 15 \\
\hline & & 1 & 21 & & \multirow{5}{*}{3} & 1 & 64 \\
\hline & & 5 & 17 & & & 5 & 52 \\
\hline & & 10 & 15 & & & 10 & 45 \\
\hline & & 20 & 13 & & & 20 & 37 \\
\hline & & 50 & 8 & & & 50 & 25 \\
\hline & \multirow{5}{*}{4} & 1 & 23 & & \multirow{5}{*}{4} & 1 & 68 \\
\hline & & 5 & 19 & & & 5 & 57 \\
\hline & & 10 & 17 & & & 10 & 50 \\
\hline & & 20 & 14 & & & 20 & 43 \\
\hline & & 50 & 10 & & & 50 & 31 \\
\hline & \multirow{5}{*}{5} & 1 & 24 & & \multirow{5}{*}{5} & 1 & 72 \\
\hline & & 5 & 20 & & & 5 & 60 \\
\hline & & 10 & 18 & & & 10 & 54 \\
\hline & & 20 & 16 & & & 20 & 47 \\
\hline & & 50 & 12 & & & 50 & 35 \\
\hline & \multirow{5}{*}{6} & 1 & 25 & & \multirow{5}{*}{6} & 1 & 74 \\
\hline & & 5 & 21 & & & 5 & 63 \\
\hline & & 10 & 19 & & & 10 & 57 \\
\hline & & 20 & 17 & & & 20 & 50 \\
\hline & & 50 & 13 & & & 50 & 38 \\
\hline \multirow{25}{*}{ \pm 10} & \multirow{5}{*}{2} & 1 & 38 & \multirow{25}{*}{ \pm 20} & \multirow{5}{*}{2} & 1 & 76 \\
\hline & & 5 & 29 & & & 5 & 58 \\
\hline & & 10 & 24 & & & 10 & 48 \\
\hline & & 20 & 19 & & & 20 & 38 \\
\hline & & 50 & 10 & & & 50 & 20 \\
\hline & \multirow{5}{*}{3} & 1 & 43 & & \multirow{5}{*}{3} & 1 & 85 \\
\hline & & 5 & 34 & & & 5 & 69 \\
\hline & & 10 & 30 & & & 10 & 60 \\
\hline & & 20 & 25 & & & 20 & 50 \\
\hline & & 50 & 16 & & & 50 & 33 \\
\hline & & 1 & 45 & & & 1 & 91 \\
\hline & & 5 & 38 & & & 5 & 76 \\
\hline & 4 & 10 & 34 & & 4 & 10 & 67 \\
\hline & & 20 & 29 & & & 20 & 58 \\
\hline & & 50 & 20 & & & 50 & 41 \\
\hline & & 1 & 48 & & & 1 & 95 \\
\hline & & 5 & 40 & & & 5 & 79 \\
\hline & 5 & 10 & 36 & & 5 & 10 & 72 \\
\hline & & 20 & 31 & & & 20 & 63 \\
\hline & & 50 & 23 & & & 50 & 46 \\
\hline & & 1 & 49 & & & 1 & 99 \\
\hline & & 5 & 42 & & & 5 & 84 \\
\hline & 6 & 10 & 38 & & 6 & 10 & 76 \\
\hline & & 20 & 33 & & & 20 & 67 \\
\hline & & 50 & 25 & & & 50 & 51 \\
\hline
\end{tabular}

しかし, 式 (1) から明らかなよらに $\sigma_{(r+l)}=\sigma_{(r-l)}$ で あるから，倍角差㧍よび 観測差の各制限値 $\hat{R}_{P}$ および $\dot{R}_{P}$ は同一な值 となる. また, $\sigma_{(r+l)} \neq \sigma_{(r-l)}$ の場合で

表-4 $\boldsymbol{\sigma}_{(r \pm l)}, \boldsymbol{n}$ および $\boldsymbol{P}$ と $\hat{\boldsymbol{R}}_{P}\left(\dot{\boldsymbol{R}}_{P}\right)$ の値 
あっても, その誤差論的違いは目盛分割誤差の取り扱い のみに起因寸るものであると思われるから，この場合で も各制限值はほぼ同一值と考えてよいであろう。

\section{(4) $\boldsymbol{\sigma}_{(r \pm l)}, n, P$ 亡 $\hat{\boldsymbol{R}}_{P}\left(\dot{\boldsymbol{R}}_{P}\right)$ との関係}

倍角差（観測差）の制限值は対回数 $n$ および採用すべ き超過確率 $P$ に対応して 表一 3 上り定められる $R_{P}{ }^{*}$ の值に倍角 (較差) の標準偏差を乗じることにより定め られる.しかし，同一の標準偏差であっても対回数およ び超過確率の各值が異なれば，制限值もそれに伴って異 なる值となる.ここに，これらのおもな関倸を整理した 結果が 表一4 である.

表一4 において $\sigma_{(\boldsymbol{r} \pm l)}$ の值は使用する器械の性能に 応じて $\alpha, \beta$ および $\gamma$ の各值を推定することにより式 (1) を用いて算出される ${ }^{5,9), 10)}$. たとえば， $\alpha= \pm 3^{\prime \prime}, \beta$ $= \pm 7^{\prime \prime}$ および $\gamma= \pm 2^{\prime \prime}$ 程度と推定されるトランシット を使用する際の倍角 (較差) の標準偏差は約 15 ” であ り, さらにこの器械を使用して 4 対回観測を行い超過確 率を $20 \%$ とする場合の倍角差（観測差）の制限値は 表 -4より約 45”であることがわかる.

なお, 公共測量作業規程によれば基隻点測量の級別に 使用すべきトランシットの種類, 採用すべき対回数, 倍 角差および観測差の各制限值が 表一5 のように定めら れている.

\section{表一5 方向観測法の運用基準 ${ }^{11}$}

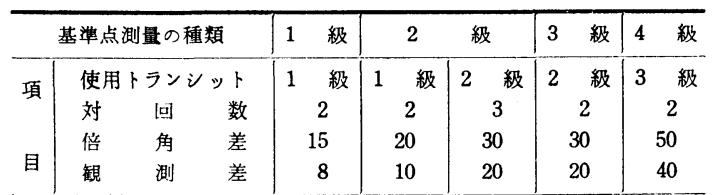

（注）左の運用基準は主として経験的な判断によって定められたと考え られる。

ここに, 1 級トランシットとは最小読定値が 1 " 以上 2 級トランシットとは最小読定值が $10^{\prime \prime}$ 以上 3 級トランシットとは最小読定值が $20^{\prime \prime}$ 以上

\section{（5） $\boldsymbol{E}(\boldsymbol{R})$ による測定值の良否判定}

一般に視準点数 $s$ に対して $n$ 対回の方向観測を行う 場合, 得られる倍角差 (観測差) の数は $(s-1)$ 個であ る．倍角差（観測差）は一種の範囲であることを考慮す ると, 測定値より得られる標本範囲 $R_{i}$ の平均值 $\bar{R}$ は

$$
\bar{R}=\sum_{i=1}^{s-1} R_{i} /(s-1)
$$

一方, 範囲 $R$ の期待值 $E(R)$ は次式で表わされる.

$$
E(R)=E\left(\sigma R^{*}\right)=\sigma E\left(R^{*}\right)
$$

使用する器械の性能に応じて式 (1) より求まる $\sigma$ と, 表一2 より対回数 $n$ に対応する $E\left(R^{*}\right)$ とを知ることに より $E(R)$ が算出される.この $E(R)$ と式 $(12)$ より
求まる $\bar{R}$ との比較を行うことにより, どの視準点に対 ししかも第何対回目を再測すればよいかを判断すること は不可能であるが，しかし観測の良否を総合的に推測す ることは可能である.

\section{3. 求心誤差の評価について}

方向観測法により角測定を行う場合, 測定值に含まれ る偶然的な誤差は倍角差（観測差）の制限値を指標とし て評価される.しかし, 倍角差 (観測差) の誤差論的特 徵を考慮すると, 前述の方法では測定值に含まれる定量 的な誤差の評価を行うことは不可能である.たとえば $m$ 個の三角形が形成される三角網においてある級の三 角測量を方向観測法により行う際, 各測点での測定值は 倍角差 (観測差) の制限值を満たしているにもかかわら ず， $m$ 個の三角形のいくつかは閉合条件が満足されな いといら不都合が生じることも十分に考えられ，この原 因は求心誤差に起因するものと思われる.

著者は前報 ${ }^{22)}$ で求心誤差が測定值に及ぼす影響を確率 論的に考究した結果, 求心誤差は可測量である視準距離 $\left(S_{1}(\mathrm{~m}), S_{2}(\mathrm{~m})\right)$ および測定角 $\left(\theta\left(0^{\circ} \leqq \theta<360^{\circ}\right)\right)$ とを 知ることにより次式で評価できることを示した.

$$
\delta=\frac{0.63 \bar{e}}{S_{1} S_{2}} \sqrt{2\left(S_{1}{ }^{2}+S_{2}{ }^{2}\right)-4 S_{1} S_{2} \cos \theta}(\mathrm{rad})
$$

ここに, $\bar{e}:$ 偏心距離の平均値 $(\mathrm{m})$

著者の実験によれば $\bar{e}=0.0005 \mathrm{~m}$ といら結果を得た が, 光学的求心装置を用いる場合一般的には $\bar{e}=0.001$ $\mathrm{m}$ 程度と考えるのが妥当であろう。 また, さげ振りに より求心を行ら際には $\bar{e}=0.005 \mathrm{~m}$ は十分に考えられる

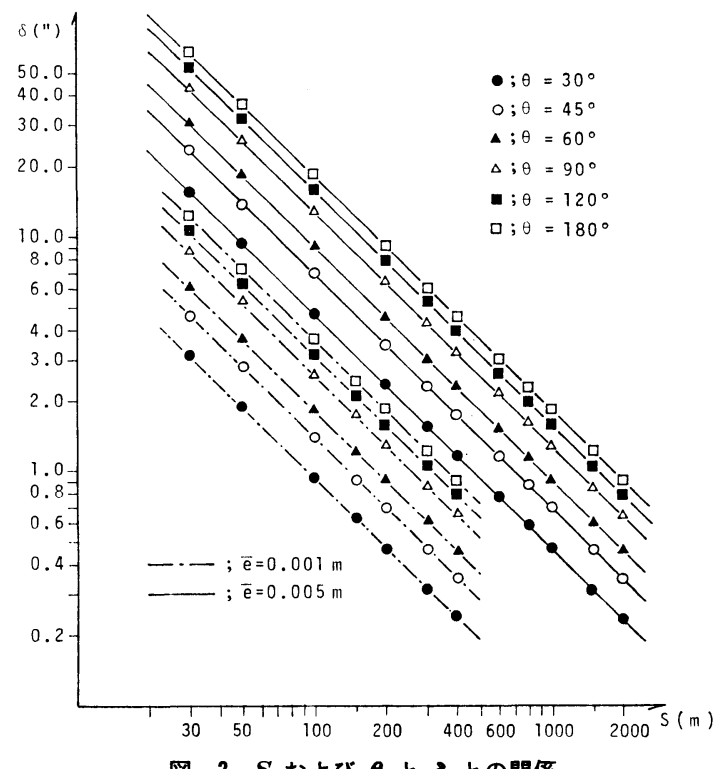


值と思われる. いま, 式 (14) において $S_{1}=S_{2}=S$ と して $\bar{e}=0.001 \mathrm{~m}$ および $\bar{e}=0.005 \mathrm{~m}$ の各場合について 視準距離 $S$, 測定角 $\theta$ および求心誤差 $\delta$ との関係を求 めた結果が 図一2 である.

図一2 2り，角測定を行う際に光学的求心装置を使用 する場合には視準距離を $400 \mathrm{~m}$ 以上に, またさげ振り による場合には視準距離を $1800 \mathrm{~m}$ 以上に取れば, 測定 值に含まれる求心誤差の影響はともに $1^{\prime \prime}$ 以下となるこ とがわかる.このことより, 測点の周囲にいくつかの挟 角を形成するすべての視準線を使用する求心装置に応じ て上記の長さに取れば, 各挟角に含まれる求心誤差の影 響を無視することが可能となり，倍角差（観測差）の制 限值を指標として測定值の良否判定を行っても先に述べ た不都合は生じないと思われる.

\section{4. 各制限値の今後の問題について}

現在おもに市販されている最小読定值が $1^{\prime \prime} \sim 20^{\prime \prime}$ の トランシット(ウィルド, 測機舎, ッアィス, トップコ ン, ニコン）を対象にその特徴を調べてみると, まずさ げ振りに代わって求心望遠鏡により求心を行い, 測微鏡 により角を読み取ることが一般的であると思われる.さ らに望遠鏡の倍率は各トランシットとも最小読定值にか かわらず一律に 30 倍, 同様に求心望遠鏡の倍率は約 2 倍 (ウィルド : 2.5 , 測機舎 $: 2.0$, ツアィス $: 2.0$, トッ プコン: 3.0 , ニコン: 2.2 倍）であることがわかる. この結果, 読み取り誤差および求心誤差が測定值に及ぼ す影響は著しく減少し, 精密な測定值を得ることができ るようになったと思われる。

著者が SDM-3C (望遠鏡倍率 20 倍, 求心望遠鏡倍 率 2 倍およびマイクロ $10^{\prime \prime}$ 両側読み）を用いて何点か の測点で 3 対回の方向観測法を行ったところ, 倍角差の

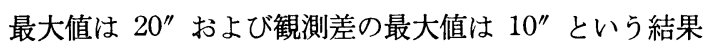
を得た（各視準距離は 60〜100 m). この結果を一応 表 一5 にあてはめるならば 1 級トランシットによる 2 級基 準点相当の測量を行ったことになる.また，20"読み卜 ランシットを使用する場合でも，20” 以下の細かい単位 まで推読することにより上記と同様な結果が得られるこ とと思われる.

一方, 通常最も一般的に使用される測微鏡付きトラン シット（20" 読み）を用いてある挟角を測定する場合測 定值に含まれる誤差は $8^{\prime \prime}$ 程度であること ${ }^{8)}$, さらに低 価格の短距離用光波測距儀（150〜500 m) が普及しつつ あることを考慮すると, 単測法だけでも 2 級基準点測量 程度の閉合差が得られることと思われる.

このように機能が著しく向上した各種測量器械が普及 し，さらに視準点に据えた反射鏡を自動的に追跡視準
し, 角および水平距離の測定值がディジタル表示される 軽量・低価格のトランシットも近い将来出現するであろ うと思われる今日, 器械の進歩が倍角差 (観測差) およ び閉合差などの各制限值とどのように関連するかを今後 検討する必要があると思われる.

\section{5. 結 語}

本研究で得られた結果を要約すると下記のとおりであ る.

(1) 範囲 $R$ の密度関数および分布関数は順序統計 量の最大值と最小值との同時密度関数より誘導される. これらの密度関数 および分布関数を標本数 2 10 の各 場合について 数值積分を行うことにより求めた 結果が 図一1である.

（2）（1）の結果を用いて $R^{*}(=R / \sigma)$ がある特定の 值 $R_{0}$ * 以下となる確率をおもな 標本数 $(2 \sim 6)$ につい て示したものが 表一1 である. また, $R^{*}$ の期待值 $E$ $\left(R^{*}\right)$ を標本数 $2 \sim 10$ の各場合について 数值積分を行 らことにより求めた結果が 表一2 である.

（3）方向観測法を行う際の倍角差および観測差は同 一視準点に対する各対回ごとの倍角および較差の各值を それぞれ 1 組の無作為標本とする範囲である. さらに範 囲の理論における標本数は方向観測法を行ら際の対回数 に対応することを考慮すると, 測定值の良否判定の指標 である倍角差および観測差の各制限值は範囲の理論を応 用して誘導することができる.

（4）（3）の結果より求まる規準化された倍角差およ び観測差の各制限值 $R_{P} *$ は測量の目的および使用する 器械に応じて種々に変化すべき性質をもつ超過確率と対 回数とに影響されることがわかる. そこで, 対回数 $n$ が 2 6 の各場合について 5 通りの超過確率 $P$ 值 $(1,5$, $10,20$ および $50 \%)$ に対する $R_{P}{ }^{*}$ の值を求めた結果 が表一3 である.

(5) $n$ 対回の方向観測を行う際に測定值の良否判定 の指標となる倍角差および観測差の実用的な各制限值は 対回数 $n$ および採用すべき超過確率 $P$ に対応して表一 3 より定められる $R_{P}^{*}$ の值に倍角および較差の各標準 偏差を乗じることにより算出される. しかし，倍角およ び較差の各標準偏差は式（1）から明らかなように同一 であることより，倍角差および観測差の各制限值も同一 な値となる.

（6）倍角 (較差) の標準偏差がある一定值であって も, 対回数および超過確率の各值が異なれば, それに伴 って測定値の良否判定の指標である倍角差（観測差）の 制限值も異なる值となる. そこで, 標準偏差, 対回数お よび超過確率と制限值との種々の関係を整理した結果が 
表-4 である.

（7）測定値より得られる倍角差（観測差）の平均值 と式 (13) より算出される範囲 $R$ の期待值との比較を 行らことにより，どの視準点に対ししかも第何対回目を 再測すればよいかを判断することは不可能であるが，し かし観測の良否を総合的に推測することは可能である.

（8）倍角差 (観測差) の誤差論的特徵を考慮する と，倍角差（観測差）の制限值を指標として測定值の良 否判定を行う従来の方法では測定值に含まれる定量的な 誤差, 特に求心誤差の評価を行うことは不可能である. そこで，式（14）を用いて視隻距離，測定角および求心 誤差との関係を求めた結果が 図一2である. 図一2より 求心を行う際に光学的求心装置を用いる場合には視淮距 離を $400 \mathrm{~m}$ 以上に，またさげ振りによる場合には視準 距離を $1800 \mathrm{~m}$ 以上にとれば求心誤差が測定值に及ぼ す影響はともに $1^{\prime \prime}$ 以下となることがわかる.

（9）機能的に著しく進歩した各種測量器械を使用す ることが一般的となり, 相当に精密度のよい測定值が得 られるようになった結果, 器械の 機能的向上が倍角差 （観測差）および閉合差などの各制限值とどのように関 連するかを今後検討する必要があると思われる.

おわりに，本研究を行うにあたり懇切なご指導をいた だいた, 中央大学理工学部 春日屋伸昌教授に謝意を表
わす次第です.

\section{参考文 献}

1) Jordan/Eggert/Kneissl : Handbuch der Vermessungskunde- Band II, J.B. Metzlersche, s. 376 382, 1963.

2) Näbauer, M. : Vermessungskunde, Springer-Verlag, s. $129 \sim 134,1941$.

3) Breed, C.B. and G.L. Hosmer: The Principles and Practice of Surveying-Vol. 1 : Elementary Surveying, 11th ed., John Wiley and Sons, pp. 64 67, 1977.

4) Kissam, P. : Surveying for Civil Engineers, 2nd ed., McGraw-Hill, pp. 132 134/140 142, 1981.

5）斉藤暢夫：基準点測量の実際, オーム社, pp. 66〜 72, 1980.

6）千葉喜味夫・千葉善夫：現場技術者のための総合測量一 上巻, 工学出版, pp. 17〜24, 1971.

7） I. ガットマン/S.S. ウィルクス (石井恵一・堀素夫共訳): 工学系のための統計概論, 培風館, pp. 201 203, 1976.

8）近津博文 : 観測角に影響 を与える 各種不定誤差とトラバ 一スの同時調整法, 測量, 第 31 巻, 第 9 号, pp. 28〜 32, 1981.

9) Davis, R.E. et al. : Surveying Theory and Practice, 6th ed., McGraw-Hill, pp. 254 257, 1981.

10）森 忠次: 測量学 1-基礎編, 丸善, pp. 171 172, 1979.

11）建設大臣官房技術調查室監修: 公共測量作業規程, 日本 測量協会, pp. 22 29, 1981.

12）近津博文 : 求心誤差が測定值に及ぼす影響について, 土 木学会論文報告集, No. 332, pp. 159 162, 1983.

(1982.5.15 - 受付) 